\title{
TOWARDS THE CONTEXTUALISATION OF DEMOCRACY: A CRITICAL PRECURSOR FOR CITIZENSHIP EDUCATION IN UNIVERSITIES
}

\section{N. Davids}

Department of Education Policy Studies

Stellenbosch University

Stellenbosch, South Africa

e-mail: nur@sun.ac.za

\section{ABSTRACT}

In response to a controversial article, which sought to draw connections between intelligence and essentialist understandings of race and ethnicity, a university Senate has adopted a motion, geared at off-setting any future research of this nature. The resort to notions and imperatives of citizenship education, as contained in this motion, raises necessary questions about how a university conceives of itself in relation to acting and being democratic. It would appear from the language and content of the motion, that should the motion be implemented, it risks slipping into yet another reductionist approach to citizenship education. In response, this article argues that citizenship education cannot be decontextualized from the space of a university in which it is expected to function and live. That is, that democratic citizenship education can only be meaningful to the extent that the principles and values of democracy are brought forth through the lived experiences of students, academics, and all others, who occupy this space.

Keywords: democratic citizenship education, university, lived experiences, contextualisation

\section{INTRODUCTION}

After the now well-known disgust surrounding the nonsensical article, entitled, "Age- and education-related effects on cognitive functioning in Coloured South African women" (Nieuwoudt et al. 2019), the proverbial dust has scattered and seemingly settled in a decision by Stellenbosch University to throw its weight behind a "focused and concerted long-term institutional response" to the issues brought to the fore by this controversial article by five female academics. A motion adopted by the Senate on 31 May 2019, reads as follows: "We believe the University should become a key site for developing a critique of race in science and research, and establishing related institutional practices and processes". In line with this motion, the following four proposals are referred "for further consideration and action": 
- That "consideration be given to instituting a campus-wide mechanism dedicated to transforming research and science";

- That "consideration be given to offering a module on anti-racism, democracy and critical citizenship to all first-year students";

- That "a suite of short courses be offered by the Research Office for all staff members" on topics such as "the use of human categories in research and science"; and

- That departments such as Gender and Critical Race Studies be institutionalised at SU.

These four proposals are not especially unique - they embody a kind of language and intent, which have accompanied institutional spaces of teaching, learning and research, in postapartheid South Africa. The only criticism might pertain to the fact that it has taken a nonsensical article to seemingly have jarred the university into a re-consciousness of what its ethical responsibility ought to be. But perhaps this is an unfair criticism. And, maybe some words of gratitude might actually be extended to the five authors of the article, for reminding us that our past is still very much our present. There are memories within all of us, as the philosopher, Mark Rowlands reminds us, that "no one ever thought to dignify with a name" $(2008,46)$. This, he explains, "is the memory of a past that has written itself on you, in your character and in the life on which you bring that character to bear" (ibid). None of these authors - I think - would consider themselves as racist. Yet, as Rowlands $(2008,46)$ informs us, even when we are not typically aware or conscious of these memories, "they, more than anything else, make you what you are". This, I believe, holds a lesson for all of us.

\section{"MEMORIES-WITHOUT-A-NAME"}

Let me return, therefore, to the lessons and trappings of the afore-mentioned four proposals. Like Rowlands's (2008) memories-without-a-name, Stellenbosch University, like any other university and school, is constructed by walls, some physical, and others symbolic - both of which contain memories. These walls might not immediately be evident - for as long as we move freely and safely through these walls, we do not necessarily see the prejudice; resistance, marginalisation and exclusion of these walls - much in the same way that we might be unconscious of certain memories, until we slam against them. These walls - named in honour of Prof Raymond William Wilcocks - enframed the very Senate in which the four proposals were adopted. The irony of this depends on an individual's vantage point - either one reflects on the inappropriateness of having any conversation about non-racism in a building, named 
after R.W. Wilcocks, or one appreciates the absurdity thereof, and considers it as some sort of triumph over the views propagated by Wilcocks. These walls, or "wall", as Ahmed $(2012,175)$ describes it, "is what we come up against"; they contain "the sedimentation of history into a barrier that is solid and tangible in the present, a barrier to change as well as to the mobility of some, a barrier that remains invisible to those who can flow into the spaces created by institutions". Until we are prepared to confirm, firstly, the existence of this wall, and its memories, we cannot bring to bear another kind of life - that is, we cannot endeavour towards democratic forms of being and engagement, unless we are prepared to take account of that which alienates and resists us.

Let's look at the proposals. We should have the expectation of any university to ensure that it holds all its academics and researchers to particular ethical standards of research, and concomitantly, to act decisively when these standards are deliberately undermined or compromised. So, too, we should expect any university, which functions in a democracy, to be perennially sensitive to issues of race, gender, (dis)ability, sexuality, culture, religion, ethnicity, nationality, language, and class. A university, therefore, should not be reminded that it has ethical responsibilities for cultivating safe and inclusive spaces of recognition and respect. As such, we should be able to leave proposals 1, 3 and 4 in the institutional hands of the university - at least, in terms of principles. It is the second proposal - that "consideration be given to offering a module on anti-racism, democracy and critical citizenship to all first-year students" - which, I believe presents the greatest concerns and challenges, because it is this proposal which speaks to the heart of the civic responsibility of any university. What kind of student does a place like Stellenbosch University produce? Not the qualification, but the person and citizen.

Let me start by stating that it is not entirely clear why this specific proposal has been included with the other three, given that the source and scope of the problem (the article) has, in fact, not been instigated by students. Of course, it would not be an exaggerated generalisation to assert that this university, like all others in South Africa, and elsewhere, have had abundant incidents of questionable and anti-social behaviour by students. The protests, for example, which disrupted university campuses across South Africa, in 2016, unleashed unprecedented forms of violence, vandalism, and hate speech among student protesters (Hall 2016; Suttner 2016). In 2017, three Stellenbosch University students displayed Nazi-inspired posters, which advertised an "Anglo-Afrikaner student" event, under the motto "Fight for Stellenbosch" in English and Afrikaans. Presumably, the thinking is that addressing students' potential (and past) deficiencies in relation to democratic being and thinking might as well be part of the institutional focus. It seems reasonable to expect and argue that universities have a moral and 
vested interest in contributing to, and sustaining the type of society in which they are located. Dewey $(1944,87)$ is well-known for contending that "A democracy is more than a form of government; it is primarily a mode of associated living, of conjoint communicated experience". From this we understand that one cannot conceive of democracy without considering the lived experiences of a society. Moreover, following Giroux $(2009,14)$, the real purpose of higher education means encouraging young people to think beyond the task of simply getting a lucrative job. Rather, at stake here, argues Giroux $(2009,14)$ "is the need to insist on the role of the university as a public sphere committed to deepening and expanding the possibilities of democratic identities, values, and relations".

It is seldom the case that we ask universities to look at schools for guidance - given the chronology of these institutions. But, now might be a good time to do so - if only in terms of policy, and its complex failings. Since the inception of outcomes based education in South Africa, in the late 1990s, and its ensuing iterations (the National Curriculum Statement (NCS); Department of Basic Education (DBE) 2002; the Revised National Curriculum Statement (RNCS); DBE 2004; and the Curriculum and Assessment Policy Statement (CAPS); DBE 2013), schools have been looked to as the producers of "good citizens" - considered by some as the core purpose of public schooling. This rationale is informed by liberal conceptions of democratic citizenship education which hold, as Levinson $(2014,4)$ argues, that no government is "intrinsically self-perpetuating, as there is no reason to think that human beings born under any particular government will naturally come to develop the knowledge, skills, and dispositions to maintain it". Moreover, there are certain civic ideals about the appropriate kinds of relationships among citizens - whether those are of equality, natural hierarchy, mutual respect, shared adoration for the fatherland, mutual non-interference, or common national identity - that are achieved only to the extent that citizens internalize and act upon these ideals (Levinson 2014, 4). To Levinson (2014), as it is to a host of liberal theorists (Callan 1997; Nussbaum 1997; Gutmann 1999; Benhabib 2011; Macedo 2000), citizenship education is necessary for the internalisation and action of being a good citizen.

In terms of CAPS (DBE 2013), for example, each subject makes reference to the cultivation of "equipping learners, irrespective of their socio-economic background, race, gender, physical ability or intellectual ability, with the knowledge, skills and values necessary for self-fulfilment, and meaningful participation in society as citizens of a free country". Presumably, a similar imperative lies at the motivation for a module on critical citizenship for first year students. The question, however, is, can a module of this nature dismantle the walls of an institution, such as Stellenbosch University? Can such a module inculcate the necessary knowledge, self-understandings and understandings of others, so that students are nurtured into 
respectful, responsible, and deliberative citizens?

We know that when we look at our South African schools, that notions and conceptions of democratic citizenship education have seldom moved beyond the theory of policy. Not only are desegregated schools in dire need of integration, inclusivity and belonging, but incidents of racism and discrimination are common occurrences among learners, and of greater concern, between teachers and learners. This, despite 25 years of concerted policy-driven efforts, within each subject, and within each grade - and with minds, which are more impressionable than those of university students. The reason for the slow (stagnant) pace of creating integrated and respectful schools is a complex one. Schools are under the mistaken impression that democratic citizenship education can be taught, without having to make that democracy part of the experience of learners and staff. In this respect, they might come to know about diversity, tolerance, deliberation, and dissensus, without actually being subjected to it. It is not unusual, for example, for learners at historically advantaged schools, to encounter only one kind of teacher in terms of race, religion and culture. And, it is equally not unusual for learners to come face to face with "the wall" (Ahmed 2012), and realise that their acceptance is dependent on the extent to which they are prepared to accept that wall. For university students, the situation is not any different. They, too, come into spaces where clearly defined norms dictate lines and divisions between dominance and obscurity, between hegemony and voicelessness.

The reality is that even if first year students had attended diverse schools, they would not necessarily have forged friendships or ties across racial, cultural, linguistic or class lines. Students, like other individuals, generally gravitate towards those, who look and think as they do. Moreover, most South African students would not have attended racially and culturally diverse schools. For obvious reasons, patterns of migration have been mostly toward historically advantaged (white) schools. These schools, therefore, would have experienced the greatest shift in terms of learner demographics, but not necessarily in terms of teacher demographics. For the most part - again, for obvious reasons - black schools, in particular, have experienced minimal (if any) shifts in learner demographics. The point is that for most first year students, entering a university space, represents the first occasion for being with students who are different and diverse. To teach to them, and to tell them about how non-racism and democratic citizenship, will not get these students to learn how to be non-racist and democratic.

\section{DEMOCRACY AS CONTEXTUALISATION}

The idea that a module directed at a first year class might somehow insert the necessary understandings of anti-racism, democracy and critical citizenship, is to reduce democratic 
citizenship education to a compulsory tick-box of attendance. It is akin to trying to teach an individual how to ride a bicycle, without actually getting onto a bicycle. Unlike schools, universities are inhabited by adults, who have already experienced their formative years, they would already harbour particular views and (mis)perceptions - put in place by their homes, friends, extended family, and their respective schools. I cannot see how a cramped first year class would lend itself to what citizenship education actually requires. What citizenship education and civic responsibility require, is for students and learners to come together - they need to bring their different backgrounds and worldviews and come into meaningful engagement and deliberation so that they can make sense of themselves, of others, and of themselves in relation to others. The potential impact of citizenship teaching, Biesta $(2011,1)$ argues, "is always mediated by what children and young people experience in their everyday lives" about democratic ways of acting and being and about their own position as citizens.

The first point of departure, therefore, of any module or programme, which seeks to inculcate the values of thinking and being democratic, is to embody that which it seeks to inculcate. These engagements and conversations do not (and should not) have to be located in the formal spaces of university lecture theatres - but rather in spaces, which lend themselves to conversations, deliberations and debates Students, more than anything, need to learn how to think, how to listen, how to consider different perspectives, and how to critically reconsider their own taken-for-granted views. Students need to be provided with spaces and opportunities whereby they can step out of who they are, and cross-over into other life-worlds and perspectives. These conversations cannot take place when there is a wall, which disallows students from being who they are, and which prevents other forms of identities from coming to the fore. It would seem, therefore, that as a starting point, universities ought to be looking at their own wall, and question whether they are providing spaces of equal belonging to all students, and academics. Any endeavour towards citizenship education must be preceded and accompanied by university spaces that are not only accessible and inviting, but justly human. We cannot conceive of what it means to be a "good citizen" without taking into account what it means to be a good or just human being. Similarly, universities cannot expect to inculcate the principles and values of critical citizenship, if the environment and conditions of the university do not promote and reflect these same values.

Secondly, citizenship education needs to be contextualised, and the context has to reflect the kinds of values, which we hope to evoke from what it means to be a just. If the intention of universities is to produce students, who are critically conscious of themselves as human beings and as citizens, then their universities have to reflect and defend the kind of knowledge, which, according to Banks $(2004,291)$, will create a humane and just world. Clearly, research, which 
inflicts harm and denigration on any group or individual, stands in contradistinction to what it means to act humanely or justly. This means that if universities wish for students to be critically aware, responsible and responsive to the world in which they find themselves, then universities have to be unconditionally open to critiquing any form of injustice. Ultimately, as Gutmann (2004) has argued, our collective and primary commitment cannot be to any human community, our commitment has to be to justice. Universities, therefore, as the epistemological and ethical spaces of students, have to be just in how they conceive of themselves, how they engage with students and staff, and they have to be seen as acting in the face of injustice. This is the kind of context, which will allow young people to live and flourish in the principles and practices of democracy.

In concluding. I wrote this article, partly in response to the decision by a Senate to adopt a particular motion, and partly to critically reflect on the problematique of universities wanting to teach about democratic citizenship education, without embodying what it means to be a democratic space. This is not to say, that if the lived spaces of universities reflect those of democratic ways of thinking, being and acting, that student or academic transgressions (as cited in this article), will not occur. Such guarantees can never be offered - least of all in a democracy, where an openness to difference necessarily implies the perpetual presence of dissensus and conflict. What is being argued for, is that where and when universities recognise their ethical responsibility to "deepening and expanding the possibilities of democratic identities, values, and relations, universities are better equipped to respond to injustices" (Giroux 2009, 14). The whole point of deepening the possibilities of democratic ways of thinking and acting, is that students have to live and experience these ways in the spaces in which they find themselves whether it is a lecture theatre, a science laboratory, residence, or the cafeteria. Universities, as diverse spaces need to be reflective of this diversity. Student and staff have to be able to identify and relate to the spaces, which they occupy. It is through these points of resonance and recognition, that students and staff find not only familiarity and belonging, but a stronger impulse to expand on what they experience. The idea that citizenship education can be relegated to a compulsory module is to treat the cultivation of citizenship as a supplementary activity, when in fact, it should be at the centre of what universities do and aspire towards.

\section{REFERENCES}

Ahmed, S. 2012. On being included: Racism and diversity in institutional life. Durham, Duke: University Press.

Banks, J. A. 2004. Teaching for social justice, diversity, and citizenship in a global world. The Educational Forum 68: 289-298.

Benhabib, S. 2011. Dignity in adversity: Human rights in troubled times. Cambridge: Polity Press. 
Biesta, G. J. J. 2011. Learning democracy in school and society: Education, lifelong learning, and the politics of citizenship. Rotterdam: Sense.

Callan, E. 1997. Creating citizens: Political education and liberal democracy. Oxford: Oxford University Press.

DBE see Department of Basic Education.

Department of Basic Education. 2002. National Curriculum Statement. Pretoria: Government Printers.

Department of Basic Education. 2004. Revised National Curriculum Statement. Pretoria: Government Printers.

Department of Basic Education. 2013. National Curriculum Statement. Pretoria: Government Printers.

Dewey, J. 1944. Democracy and education: An introduction to the philosophy of education. New York: The Free Press.

Giroux, H. A. 2009. Education and the crisis of youth: Schooling and the promise of democracy, The Educational Forum 73: 8-18.

Gutmann, A. 1999. Democratic education. New York: John Wiley \& Sons.

Gutmann, A. 2004. Unity and diversity in democratic multicultural education: Creative and destructive tensions. In Diversity and citizenship education: Global perspectives, ed. J. A. Banks, 71-96. San Francisco: Jossey-Bass.

Hall, M. 2016. South Africa's student protests have lessons for all universities. Higher Education Network. https://www.theguardian.com/highereducationnetwork/2016/mar/03/south-africasstudent-protests-have-lessons-for-all-universities (Accessed 5 June 2019).

Levinson, M. 2014. Citizenship and civic education. In Encyclopedia of Educational Theory and Philosophy, ed. Denis C. Phillips. Thousand Oaks, CA: Sage. http://nrs.harvard.edu/urn3:HUL.InstRepos:12701475 (Accessed 31 May 2019).

Macedo, S. 2000. Diversity and distrust: Civic education in a multicultural democracy. Cambridge: Harvard University Press.

Nieuwoudt, S., K. E. Dickie, L. Engelbrecht and E. Terblanche. 2019. Retracted article: Age- and education-related effects on cognitive functioning in Colored South African women, Aging, Neuropsychology and Cognition: A Journal on Normal and Dysfunctional Development, https://doi.org/10.1080/13825585.2019.1598538 (Accessed 10 June 2019).

Nussbaum, M. 1997. Cultivating humanity: A classical defence of reform in liberal education. Cambridge, Massachusetts: Harvard University Press.

Rowlands, M. 2008. The philosopher and the wolf. London: Granta Publications.

Suttner, R. 2016. Op-Ed: Student protests, an indictment of "post-apartheid" South Africa. December $2017 . \quad$ www.dailymaverick.co.za/.../2016-02-11-op-ed-student-protests-anindictment-of-po (Accessed 5 June 2019). 